\title{
STUDENTS' ATTITUDES AND BEHAVIOURS IN THE CONTEXT OF ENVIRONMENTAL ISSUES
}

\author{
Nena Rončević and Klara Cvetković
}

\author{
Department of Education \\ Faculty of Humanities and Social Sciences \\ University of Rijeka \\ Sveučilišna avenija 4, 51000 Rijeka \\ e-mail: nena.roncevic@ffri.uniri.hr
}

\begin{abstract}
The aim of this paper is to describe and analyse attitudes and behaviours of the student population $(N=1347)$ of the University of Rijeka towards environmental issues. Data were collected during the summer semester of the 2015/2016 academic year. Paper seeks to explore the connection between the following measured concepts: socio-ecological orientations, pro-environmental behaviour, ethos types, and preference for the development paradigm, as well as the differences in relation to independent variables. Research results reveal that students predominantly prefer the holistic ethos type of responsibility (82.2\%) and that the majority of students still support the new environmental paradigm, i.e. the claim "slower economic development, accompanied by stronger environmental protection", which is consistent with the results from other studies. Furthermore, contingency analysis revealed significant associations with regards to gender and year of study. Males mostly prefer the egocentric ethos type of responsibility as well as the claim "faster economic development, accompanied by greater environmental pollution", while females mostly prefer the holistic ethos type and the new environmental paradigm. Students who are at the beginning of their higher education prefer egocentric, utilitarian and biocentric ethos types, while students who are in their final years of study prefer the holistic ethos type of responsibility and the new environmental paradigm. As for socio-ecological orientations, statistically significant differences were found with regards to almost all independent variables: ethos types of responsibility, gender, year of study, field of study, preference for the development paradigm and the level of education of the father, while mother's level of education was not statistically signifcant. Statistically significant differences were also found with regards to pro-environmental behaviour scale on which female participants, students in their final years of study and those who prefer the new environmental paradigm rank higher in comparison to male participants, students at the beginning of their study and those who prefer the claim "faster economic development, accompanied by greater environmental pollution". In other words, it seems that the duration of study and gender are related to an increased sense of responsibility towards the environment, which is an important finding that should influence educational policies.
\end{abstract}

Keywords: students, socio-ecological orientations, ethos types, development paradigms, pro-environmental behaviour, education 


\section{INTRODUCTION}

During the last several decades, climate change and environmental pollution as the cause of various problems, e.g. the disappearance and extinction of plant and animal species, the problem of waste accumulation and management, fresh water scarcity on Earth, etc., have been frequent topics of discussion. The causes of these changes are rooted in human actions, namely industrialisation and uncontrollable development of technology, destruction of natural habitats and resources. The possible consequences of human actions are not entirely predictable, but scientists around the world warn about the climate change which could have far-reaching consequences on human survival. Humans are becoming increasingly aware of the need for pro-environmental behaviour (the use of renewable energy sources, waste separation and recycling, attention to organic diet, etc.). Therefore, the increase in environmental problems should not be simply ignored, since it necessitates the formation of new knowledge and values that would contribute to the ecological modernisation of society (Prittwitz, 1993, as cited in Cifrić, 2005); that is, that would contribute to finding a solution to environmental issues. It is necessary for humans to form an awareness of and a responsibility towards the negative consequences for society and the environment, which highlights the need for education respectful of the values of nature and environment.

Due to the aforementioned, an increase in the number of studies which would determine the state of the environmental awareness, the attitude structure, and the level of pro-environmental behaviour is of great importance as a basis for the direction of the social and especially educational practice. Taking that into account, this paper aims to contribute to the discussion on this issue.

In the socio-ecological perspective which is structured on a number of empirical studies, the following concepts are present: socio-ecological orientations, ethos types, and development paradigms of society. The concept of socio-ecological orientations developed by Ivan Cifrić (1990a, 1990b, 1992, 1994a, 1994b, 1995, 2004) found prominence among some less accepted concepts, and was accepted by other authors who used it as a basis for their research. The construct of socio-ecological orientations consists of three latent, independent dimensions within the participants' attitudes. One of them is anthropocentrism with its basic premise that humans are superior to nature, the absolute masters of nature in which they live and can behave towards it as they please. This is followed by technocentrism whose advocates think that only the belief in technology can ensure humankind's progress and provide a solution to ecological crises. The third orientation is naturalism which perceives humans as part of nature and subject to its laws, and stipulates that nature preservation should be society's priority. This concept provides the basis for the classification of the levels of human responsibility with regard to natural and social reality, called ethos types in the aforementioned theoretical concept. Four levels of responsibility are identified: egocentrism, in which ethos is focused on humans as the highest value and humans are at the centre of all activities; utilitarianism, in which the behaviour is justified if it is useful, i.e. if it is beneficial for all humankind; biocentrism, in which human responsibility extends to all living beings, 
and excludes only non-living nature; and holism, which represents the opinion that humans are responsible for the entire natural world (humans are part of the natural system) (Cifrić, 1996, 1997a, 1997b, 1998a). Furthermore, contemporary discussions on environmental issues put a special emphasis on the necessity for changes in human behaviour towards the environment / nature, production and use of natural resources. One of the approaches advocates for the adoption of a new environmental paradigm (Dunlap, 2000; 2008; Kufrin, 2004a; Kufrin and Domac, 2004b), which is based on the belief that a slower economic development accompanied by stronger environmental protection is important, as opposed to the existing pattern of action which advocates a faster economic development accompanied by greater environmental pollution.

A number of studies have focused on examining the connection between the attitudes and behaviour, and the results have shown that attitudes do influence pro-environmental behaviour. For example, the research that was conducted in Romania in 2014 (Crumpei et al.) explored the environmental attitudes of psychology students and their ecological moral reasoning. The results of this research reveal that most students are internally motivated for pro-environmental behaviour; however, during the selection of the ecological moral dilemma, two thirds of them did not choose the ecological alternative. Crumpei et al. (2014) conclude that even though attitudes have an important role in predicting ecological behaviour, there are other factors that influence the connection between proenvironmental attitudes and behaviour. Similar results were obtained by de Leeuw et al. (2014) who attempted to identify the beliefs and independent variables which motivate the pro-environmental behaviour of youths; i.e. high-school students. The differences in responses with regard to sex were identified: female students displayed more positive attitudes, stronger moral obligations towards environmental preservation, and stronger tendencies towards pro-environmental behaviour than the male participants (de Leeuw et al., 2014). Empathy emerged as an important factor in the adoption of pro-environmental behaviour; in other words, the difference between the participants with low and high levels of empathy was determined. According to the results of this research, the participants who displayed a higher level of empathy also displayed more positive attitudes, a higher level of moral obligation to adopt pro-environmental behaviours, and more often engaged in pro-environmental actions (de Leeuw et al., 2014). The research conducted in 2012 focused on students from countries with different levels of economic status (USA, Spain, Mexico and Brazil) and analysed the influence of sustainable development education on pro-environmental behaviour. The differences between the students from developed countries and emerging countries were determined, which pointed towards the influence of external factors (culture, the country's environmental structure, etc.) on the development of pro-environmental behaviour. The results reveal the exceptional importance of motivation and perceived effectiveness on pro-environmental behaviour. Additionally, this research confirms the influence of sex on pro-environmental behaviour: women are more inclined to pro-environmental behaviour in both developed and emerging countries (Vicente et al., 2012). Differences between sexes were also observed in the research that was conducted in Turkey at the 
Faculty of Architecture (the goal of this research was to examine the students' attitudes towards and awareness of environmental protection). Once again, female students displayed higher environmental sensitivity. Data regarding university departments are also interesting: the students of urban and regional planning displayed higher environmental sensitivity than students of other departments at the Faculty of Architecture in Gaza (Duman-Yuksel and Ozkazanc, 2015). The research titled "Values, identity and proenvironmental behaviour" confirmed the hypothesis that pro-environmental attitudes and values influence the behaviour directed towards environmental preservation and protection. The goal of this research was to examine the role of attitudes and identities in explaining individual pro-environmental behaviour. Identity and attitudes emerged as great predictors of pro-environmental behaviour (Gatersleben et al., 2014).

However, even though many studies reveal a highly developed environmental sensitivity, especially in students, their pro-environmental behaviours are often not aligned with their attitudes, since they depend not only on their personal beliefs and attitudes, but on their economic possibilities as well (Thompson and Gasteiger, 1985; Gigliotti, 1992; Imandoust and Gadam 2007; Chien and Shih, 2007, as cited in Müderrisoğlu and Altanlaru, 2011). The authors wanted to examine the existence of differences between environmental attitudes and behaviour, and the influence of sex and type of faculty on the stated variables. The results did not show a correlation between the faculty and proenvironmental attitudes and behaviour. On the contrary, the students at the Faculty of Forestry, who have the largest number of courses devoted to environmental protection and preservation, participate in less environmental activities than students at other faculties. The difference was determined when it comes to the participant's sex; as in the previous studies, women's attitudes and behaviours towards environmental protection are more developed than men's. The results obtained in this research demonstrate that sex has a strong influence on environmental attitudes and behaviours. This research also shows a decrease in the environmental activism of students (especially recycling), and the authors conclude the article with the question of how to find a solution for the said decrease (Müderrisoğl and Altanlar, 2011). The research of the authors Prabawa-Sear and Baudains (2011) also examined the relationship between students' attitudes and behaviour, as well as their statements on the barriers and motivators for environmentally responsible behaviour. The attitudes were measured using the Likert scales. The results revealed that it was easier to agree with the statement "I will spend less than five minutes in the shower" than to actually perform the action. Furthermore, the authors propose involving the students in the planning and decision-making process, as well as in improving the existing infrastructure (e.g., recycling), which would help to change the social trends and increase their motivation for conscientious behaviour. Additionally, this research highlights four key areas that influence environmentally responsible behaviour: personal perspective, social influences, environmental education, and the barriers that prevent environmentally responsible behaviour. Unanue et al. (2016) also highlight the importance of intrinsic motivation for the development of pro-environmental behaviour. In their research, they examine the connection between the intrinsically (self-development, 
community involvement, developing relationships) and extrinsically motivated life goals (acquiring wealth and fame, etc.), as well as the influence on environmentally responsible behaviour by using data from the longitudinal research conducted in Great Britain and Chile. In both countries, the intrinsically motivated life goals were connected to the environmentally responsible behaviour. The authors consider the extrinsic motivation to be a negative influence on the preservation of nature and natural resources because it stimulates a materialistic lifestyle, i.e. an excessive consumption of goods and services which can lead to greater negative environmental consequences. After the analysis of correlational and longitudinal data, it was determined that the type of life goals (intrinsic and extrinsic) has a greater influence on environmental action than on pro-environmental attitudes and environmental identification (Unanue et al., 2016).

\section{METHODOLOGY}

\subsection{Research purpose, goals and hypotheses}

The purpose of the research is to explore the attitudes of the University of Rijeka's student population towards environmental issues on the basis of the previously described theoretical framework. In the process, the following particular goals will be explored: 1 . determining the structure of socio-ecological orientations; 2 . affiliation to ethos types; 3. acceptance of the competing development paradigms; and 4. level of the pro-ecological behaviour of the University of Rijeka's student population.

The stated research goals generated four basic hypotheses:

It is expected that within the structure of the students' socio-ecological orientations, the most represented orientation will be naturalism whose advocates believe that humans are part of nature and subject to its laws, and that nature preservation should be society's priority.

Within the structure of the ethos types, the most represented will be the ethos type of the highest level, holism, according to which humans are responsible for the entire natural world.

The majority of students predominantly support the new environmental paradigm which puts an emphasis on the slower economic development accompanied by stronger environmental protection.

Students demonstrate a low level of pro-ecological behaviour.

In addition to the stated research purpose, there is an expectation that based on the attained results the research could lead to some practical consequences regarding the curriculum programming of the university study programmes.

\subsection{Population and sample}

The research population included all the University of Rijeka students who are in the initial or final stages of their higher education. The sample was representative for the aforementioned population. A valid survey questionnaire was completed by 1,347 Uni- 
versity of Rijeka students in total. Data were collected during the summer semester of the $2015 / 2016$ academic year. In some of the graduate or integrated study programmes, the summer semester of the senior year is the students' final semester during which they have the sole obligation to work on their senior thesis. Taking into account the aforementioned, the students enrolled in the preceding academic years (i.e. the $4^{\text {th }}$ or $5^{\text {th }}$ year of the integrated studies, and the $1^{\text {st }}$ year of graduate studies) were used as substitutes. A total of 850 participants (63.10\%) enrolled in the first year of an undergraduate study programme or an integrated study programme, and 497 participants (36.90\%) enrolled in the fourth or fifth year of the graduate study programme took part in the research. The survey questionnaire was completed by $66.5 \%$ female and $33.5 \%$ male participants in total.

Table 1. Frequencies $(f)$ and percentages (\%) with regard to the variable of Faculty

\begin{tabular}{|c|l|c|c|}
\hline \multicolumn{1}{|c|}{ Faculty } & $\mathrm{f}$ & $\%$ \\
\hline 1. & Academy of Applied Arts & 59 & 4.4 \\
\hline 2. & Faculty of Economics & 78 & 5.8 \\
\hline 3. & $\begin{array}{l}\text { Faculty of Tourism and Hospitality } \\
\text { Management }\end{array}$ & 161 & 12 \\
\hline 4. & Faculty of Humanities and Social Sciences & 96 & 7.1 \\
\hline 5. & Faculty of Civil Engineering & 109 & 8.1 \\
\hline 6. & Faculty of Medicine & 132 & 9.8 \\
\hline 7. & Department of Biotechnology & 79 & 5.9 \\
\hline 8. & Department of Physics & 33 & 2.4 \\
\hline 9. & Department of Informatics & 72 & 5.3 \\
\hline 10. & Department of Mathematics & 70 & 5.2 \\
\hline 11. & Faculty of Maritime Studies & 87 & 6.5 \\
\hline 12. & Faculty of Engineering & 61 & 9.8 \\
\hline 13. & Faculty of Teacher Education & 121 & 4.5 \\
\hline 14. & Faculty of Law & 57 & 9.0 \\
\hline 15. & Faculty of Health Care Studies & 1.347 & 4.2 \\
\hline & & & $100 \%$ \\
\hline
\end{tabular}

\subsection{Research instruments}

For the requirements of this paper, the results obtained through several previously validated instruments will be presented:

1. Instrument of socio-ecological orientations. The measurement instrument was tested several times through what is called cross-validation; therefore, three scales were created in this paper for the purpose of analysis: the scales of anthropocentrism, naturalism and technocentrism (alpha=0.632) (Cifrić, 1990a, 1992, 1994a, 1994b, 1995, 1998, 2004, 2007; Rončević and Rafajac, 2012); 
2. Ethos types: egocentrism: ethos focused on humans as the highest value where humans are at the centre of all activities, and a statement used to measure this attitude is: "Humans are responsible solely for themselves; that is, for their species."; utilitarianism: behaviour is justified if it is useful, i.e. if it is beneficial for all humankind, and a statement connected to utilitarianism is: "Human responsibility extends to plants and animals useful to them."; biocentrism: human responsibility extends to all living beings, and excludes only non-living nature with the statement: "Human responsibility extends to all plant and animal species."; and holism: ethos which represents the opinion that humans are responsible for the entire natural world, i.e. humans are part of the natural system, along with the corresponding statement: "Human responsibility extends to the entire plant and animal world." (Cifrić, 1996, 1997a, 1997b, 1998);

3. "Forced" selection of development strategy (Domac et al., 2004; Kufrin et al., 2004); and

4. Scale of pro-environmental behaviour (Bertoldo, 2014).

\subsection{Variables}

On the basis of previous research and cross-validation, the following scales were constructed on the instrument of socio-ecological orientations: the anthropocentrism scale, the naturalism scale, and the technocentrism scale. Internal consistency was tested through Cronbach's alpha: the anthropocentrism scale is alpha $=0.712$, the naturalism scale is alpha $=0.683$, and the technocentrism scale is alpha $=0.632$. The pro-environmental behaviour scale was also constructed, and its value is alpha $=0.0771$. The variable of ethos types and the "forced" selection of development paradigm are separate particles. In order to explore the differences between the groups, other independent variables which emerged as significant in the studies on environmental issues were applied: sex and year of study, field of study, and the parents' level of education. The field of study variable was created by recoding the variable of faculty (Table 1). Four fields were created: the field of humanities / social sciences and arts, the field of natural sciences, the field of technical and biotechnical sciences, and the field of biomedicine and medicine. The level of education variable included four categories: 1. (non)completed primary school; 2. completed secondary school; 3. completed two-year college / pre-Bologna graduate degree; 4 . master's degree / doctoral degree. ${ }^{1}$

\subsection{Data collection}

The research was issued a permit by the Ethics Committee of the Faculty of Humanities and Social Sciences at the University of Rijeka. With the consent of the Vice Dean for Academic Affairs, the research team contacted the professors during whose lectures data were collected. Data collection lasted from March to May 2016, and was conducted

1 The research was conducted in 2010 for the first time, for the purpose of a doctoral thesis; therefore, the same particle for measuring the level of education was applied even though the following would be more appropriate: 4. Master of Science. Nevertheless, the starting point was the presupposition that parents did not complete their studies according to the Bologna classification. 
at the beginning or end of the lectures. The duration of the process was from 15 to 20 minutes and participation was voluntary and anonymous. The research topic and the possibility of withdrawing from participation were explained to the participants.

\subsection{Data processing}

Data processing was conducted through the Statistical Package for the Social Sciences (IBM SPSS, 23.0). For data processing, the methods of univariate statistics were applied (percentages, measures of central tendency, and measures of variation), as well as the methods of bivariate statistics (the T-test, and simple analysis of variance) in order to determine the differences with regard to the defined independent variables and the chi-square test. The chi-square tests were used to determine if there was a contingency association between the studied phenomena, and statistically significant differences were interpreted through the adjusted standardised residuals. The tests for the statistical significance of the groups' average results were conducted through the analysis of variance, with the application of appropriate post-hoc tests (Hochberg GT2 test for the homogeneous variance, and the Games-Howell for the heterogeneous variance, due to the difference in group sizes) (Field, 2013). All the tests were conducted at the risk level of $5 \%$. A statistically significant difference was evaluated from the effect size aspect, from 0.01 to 0.05 being a small effect size, from 0.06 to 0.13 a medium effect size, and from 0.14 a large effect size (Cohen, 1988; Miles and Shevlin, 2001). The effect size is an objective and standardised measure of the size of the observed influence, and it assists in the interpretation of the obtained statistical significance, especially in the cases of large samples when even a negligible difference can often prove to be statistically significant.

\section{RESEARCH RESULTS}

\subsection{Ethos types and selection of the development paradigm}

The University of Rijeka students predominantly represent the holistic ethos type of responsibility (82.2\%). However, the obtained indicator significantly deviates from the results of the research conducted in 1997 on the sample of University of Zagreb students, when $91.4 \%$ of the students represented the holistic attitude (Cifrić, 1998a). The anthropocentric and utilitarian approaches are acceptable to $7.9 \%$ of the participants, while $9.7 \%$ recognised themselves in the biocentric type of responsibility.

Table 2. Ethos types

\begin{tabular}{|l|l|c|c|}
\hline & \multicolumn{1}{|c|}{$\mathrm{f}$} & $\%$ \\
\hline 1. & $\begin{array}{l}\text { Humans are responsible solely for themselves; that is, for their } \\
\text { species (egocentrics). }\end{array}$ & 43 & 3.2 \\
\hline 2. & $\begin{array}{l}\text { Human responsibility extends to plants and animals useful to them } \\
\text { (utilitarians). }\end{array}$ & 63 & 4.7 \\
\hline
\end{tabular}




\begin{tabular}{|l|l|c|c|}
\hline 3. & $\begin{array}{l}\text { Human responsibility extends to all the plant and animal species } \\
\text { (biocentrics). }\end{array}$ & 131 & 9.8 \\
\hline 4. & $\begin{array}{l}\text { Human responsibility extends to the entire plant and animal world } \\
\text { (holists). }\end{array}$ & 1098 & 82.2 \\
\hline Total & 1335 & 100.0 \\
\hline
\end{tabular}

The values are expressed in $f=$ frequencies and $\%=$ percentages.

The $\chi^{2}$ test was conducted to determine the existence of the contingency association between sex and ethos types. The analysis of the contingency table (Table 3) has shown a statistically significant relationship between sex and ethos types: $\chi^{2}(3, N=1333)=$ 15.639, $\mathrm{p}=0.001 ; \mathrm{C}=0.108$. The comparison of empirical and theoretical frequencies has revealed that men are more represented in the category of the egocentric ethos type, while women are more represented in the group of the holistic ethos type.

Table 3. Contingency table: sex and ethos types

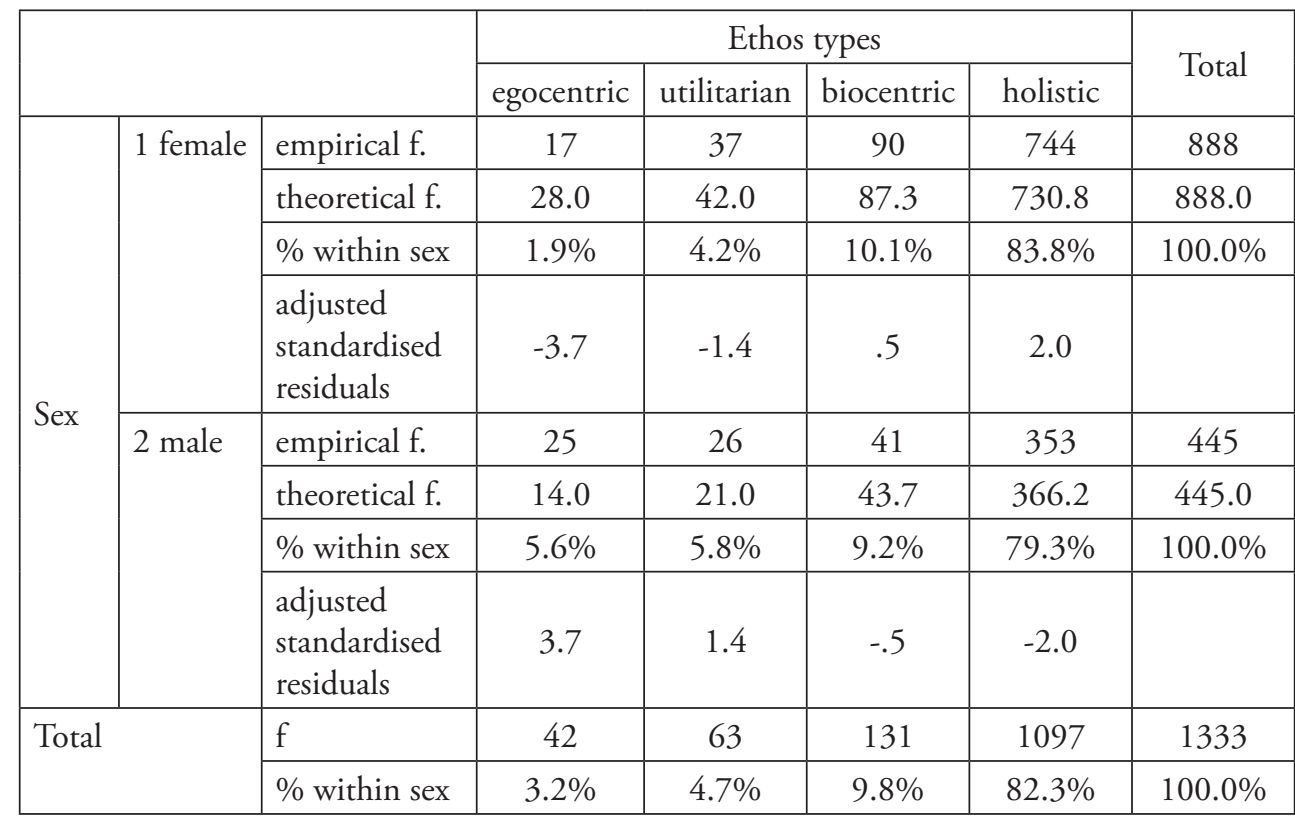

The $\chi^{2}$ test was conducted to determine the existence of the contingency association between the year of study and ethos types. The analysis of the contingency table (Table 4) has shown a statistically significant relationship between the year of study and ethos types: $\chi^{2}(3, N=1335)=17.244, \mathrm{p}=0.001 ; \mathrm{C}=0.113$. The comparison of empirical and theoretical frequencies has revealed that the students in the initial stages of higher education are more represented in the categories of the egocentric, utilitarian and biocentric ethos types, while the students in the final years of study are more represented in the group of the holistic ethos type. 
Table 4. Contingency table: year of study and ethos types

\begin{tabular}{|c|c|c|c|c|c|c|c|}
\hline & \multicolumn{4}{|c|}{ Ethos types } & \multirow{2}{*}{ Total } \\
\hline & & & egocentric & utilitarian & biocentric & holistic & \\
\hline \multirow{8}{*}{$\begin{array}{l}\text { Year of } \\
\text { study }\end{array}$} & \multirow[t]{4}{*}{1 . } & empirical f. & 34 & 49 & 93 & 664 & 840 \\
\hline & & theoretical f. & 27.1 & 39.6 & 82.4 & 690.9 & 840.0 \\
\hline & & $\%$ year of study & $4.0 \%$ & $5.8 \%$ & $11.1 \%$ & $79.0 \%$ & $100.0 \%$ \\
\hline & & $\begin{array}{l}\text { adjusted } \\
\text { standardised } \\
\text { residuals }\end{array}$ & 2.2 & 2.5 & 2.0 & -4.0 & \\
\hline & \multirow[t]{4}{*}{2.} & empirical f. & 9 & 14 & 38 & 434 & 495 \\
\hline & & theoretical f. & 15.9 & 23.4 & 48.6 & 407.1 & 495.0 \\
\hline & & $\%$ year of study & $1.8 \%$ & $2.8 \%$ & $7.7 \%$ & $87.7 \%$ & $100.0 \%$ \\
\hline & & $\begin{array}{l}\text { adjusted } \\
\text { standardised } \\
\text { residuals }\end{array}$ & -2.2 & -2.5 & -2.0 & 4.0 & \\
\hline \multirow{2}{*}{\multicolumn{2}{|c|}{ Total }} & $\mathrm{f}$ & 43 & 63 & 131 & 1098 & 1335 \\
\hline & & $\%$ year of study & $3.2 \%$ & $4.7 \%$ & $9.8 \%$ & $82.2 \%$ & $100.0 \%$ \\
\hline
\end{tabular}

The difference was not obtained with regard to the following variables: mother's level of education, father's level of education, and field of study.

In the context of the forced selection of development strategy (Domac et al., 2004a), 22.2\% of the students believe that Croatia is in need of faster economic development accompanied by greater environmental pollution, while $74.3 \%$ selected an attitude which supports the new environmental paradigm. The stated result differs notably from the result of the research conducted in 2004 (Domac et al.) on the accidental sample of the citizens of Zagreb and Rijeka, in which $87.9 \%$ of the participants supported slower economic development accompanied by stronger environmental protection.

Table 5. "Forced" selection of development strategy

\begin{tabular}{|l|c|c|}
\hline & $\mathrm{f}$ & $\%$ \\
\hline $\begin{array}{l}\text { 1. Faster economic development accompanied by greater environmental } \\
\text { pollution }\end{array}$ & 299 & 22.2 \\
\hline $\begin{array}{l}\text { 2. Slower economic development accompanied by stronger environmental } \\
\text { protection }\end{array}$ & 1001 & 74.3 \\
\hline No response & 47 & 3.5 \\
\hline Total & 1347 & 100.0 \\
\hline
\end{tabular}

The values are expressed in $f=$ frequencies and $\%=$ percentages.

The $\chi^{2}$ test was conducted to determine the existence of the contingency association between sex and the selection of development paradigm. The analysis of the contingency 
table (Table 6) has shown a statistically significant relationship between sex and the selection of development paradigm: $\chi^{2}(\mathrm{df}=1, \mathrm{~N}=1298)=44.459, \mathrm{p}=0.000, \chi=-0.184$. The comparison of empirical and theoretical frequencies has revealed that men are more represented in the selection category of faster economic development accompanied by greater environmental pollution, while women are more represented in the selection category of new environmental paradigm.

Table 6. Contingency table: sex and preference of the development paradigm

\begin{tabular}{|c|c|c|c|c|c|}
\hline & & & \multicolumn{2}{|c|}{$\begin{array}{c}\text { preference of development } \\
\text { paradigm }\end{array}$} & \multirow[b]{2}{*}{ Total } \\
\hline & & & $\begin{array}{c}1 \text { faster } \\
\text { economic } \\
\text { development } \\
\text { accompanied } \\
\text { by greater } \\
\text { environmental } \\
\text { pollution } \\
\end{array}$ & $\begin{array}{c}2 \text { slower } \\
\text { economic } \\
\text { development } \\
\text { accompanied } \\
\text { by stronger } \\
\text { environmental } \\
\text { protection }\end{array}$ & \\
\hline \multirow{8}{*}{ Sex } & \multirow[t]{4}{*}{1 female } & empirical f. & 152 & 719 & 871 \\
\hline & & theoretical f. & 200.0 & 671.0 & 871.0 \\
\hline & & $\%$ within sex & $17.5 \%$ & $82.5 \%$ & $100.0 \%$ \\
\hline & & $\begin{array}{l}\text { adjusted } \\
\text { standardised } \\
\text { residuals }\end{array}$ & -6.7 & 6.7 & \\
\hline & \multirow[t]{4}{*}{2 male } & empirical f. & 146 & 281 & 427 \\
\hline & & theoretical f. & 98.0 & 329.0 & 427.0 \\
\hline & & $\%$ within sex & $34.2 \%$ & $65.8 \%$ & $100.0 \%$ \\
\hline & & $\begin{array}{l}\text { adjusted } \\
\text { standardised } \\
\text { residuals }\end{array}$ & 6.7 & -6.7 & \\
\hline \multirow{2}{*}{\multicolumn{2}{|c|}{ Total }} & $\mathrm{f}$ & 298 & 1000 & 1298 \\
\hline & & $\%$ within sex & $23.0 \%$ & $77.0 \%$ & $100.0 \%$ \\
\hline
\end{tabular}

The $\chi^{2}$ test was conducted to determine the existence of the contingency association between the year of study and the selection of development paradigm. The analysis of the contingency table (Table 7) has shown a statistically significant relationship between sex and the selection of development paradigm: $\chi^{2}(\mathrm{df}=1, \mathrm{~N}=1300)=5.941 \mathrm{p}=0.001$, $\chi=-0.068$. The comparison of empirical and theoretical frequencies has revealed that the students in the initial stages of higher education are more represented in the selection category of faster economic development accompanied by greater environmental pollution, while the students in their final years of study are more represented in the selection category of new environmental paradigm. 
Table 7. Contingency table: year of study and preference of the development paradigm

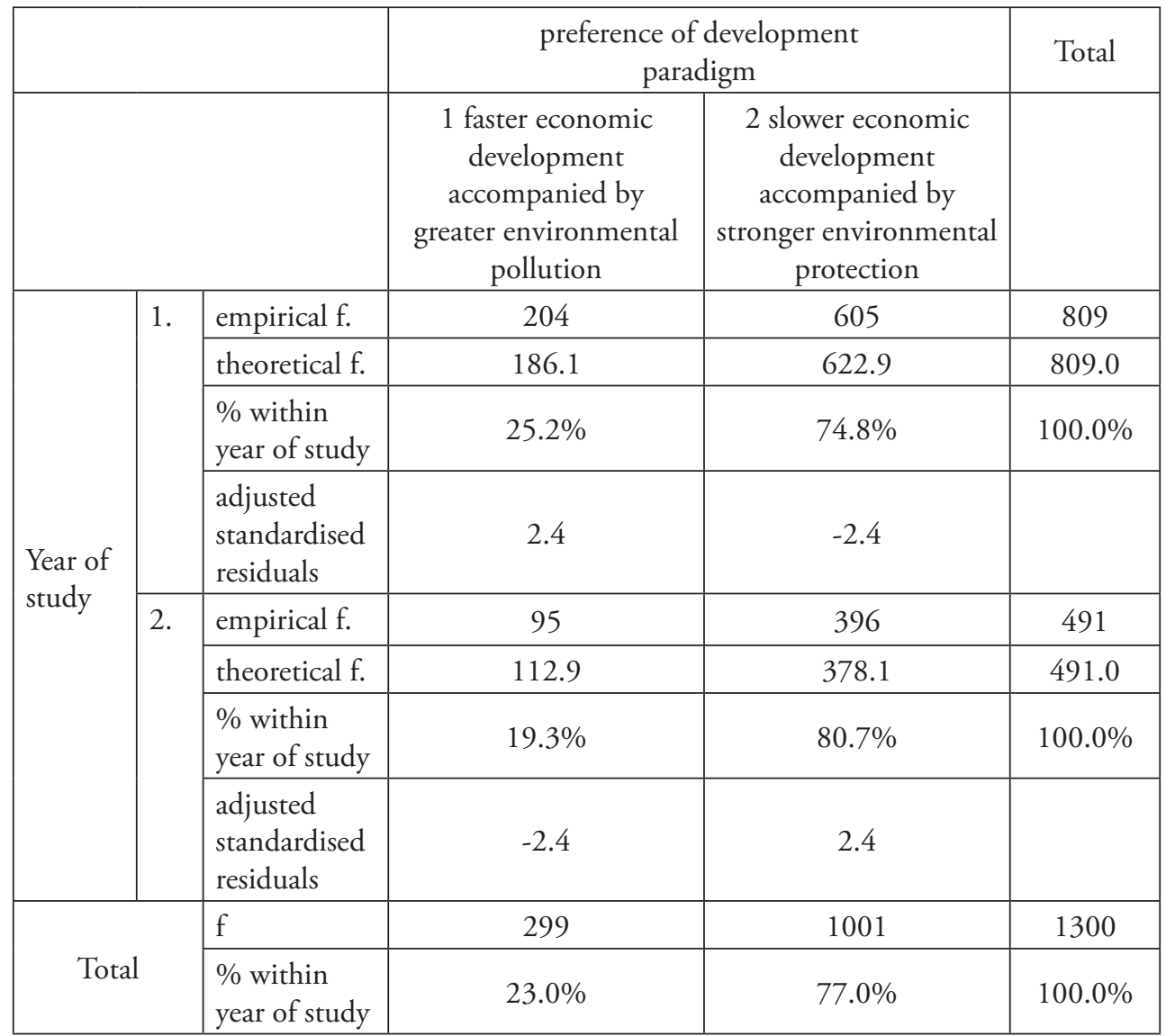

The difference was not observed with regard to the following independent variables: mother's level of education, father's level of education, and field of study.

Furthermore, the contingency association between ethos types and the selection of development paradigm was determined through the application of the chi-square test: $\chi^{2}$ $(3, \mathrm{~N}=1298)=48.447, \mathrm{p}=0.000$. The comparison of empirical and theoretical frequencies has revealed that the egocentric, utilitarian and biocentric ethos types are more represented than expected in the selection of the response faster economic development accompanied by greater environmental pollution, while the holistic type is more represented in the selection of the ecological development paradigm (Table 8). ${ }^{2}$

2 The contingency association between the year when the research was conducted (2010 compared to $2016)$ and the ethos types $\left(\chi^{2}(3, N=2327)=4.235, \mathrm{p}>0.05\right)$ was not determined, nor the contingency association between the year when the research was conducted (2010 compared to 2016) and the selection of the development paradigm $\left(\chi^{2}(3, N=2365)=1.315, \mathrm{p}>0.05\right)$. The cohorts from 2010 and 2016 have the same response patterns. 
Table 8. Contingency table: ethos types and preference of the development paradigm

\begin{tabular}{|c|c|c|c|c|c|}
\hline & \multicolumn{2}{|c|}{$\begin{array}{c}\text { preference of development } \\
\text { paradigm }\end{array}$} & \multirow[b]{2}{*}{ Total } \\
\hline & & & $\begin{array}{c}1 \text { faster } \\
\text { economic } \\
\text { development } \\
\text { accompanied } \\
\text { by greater } \\
\text { environmental } \\
\text { pollution } \\
\end{array}$ & $\begin{array}{c}2 \text { slower } \\
\text { economic } \\
\text { development } \\
\text { accompanied } \\
\text { by stronger } \\
\text { environmental } \\
\text { protection }\end{array}$ & \\
\hline \multirow{16}{*}{$\begin{array}{l}\text { Ethos } \\
\text { types }\end{array}$} & \multirow{4}{*}{ egocentric } & empirical f. & 23 & 16 & 39 \\
\hline & & theoretical f. & 9 & 30 & 39 \\
\hline & & $\%$ responsibility & $59.0 \%$ & $41.0 \%$ & $100.0 \%$ \\
\hline & & $\begin{array}{l}\text { adjusted standardised } \\
\text { residuals }\end{array}$ & 5.4 & -5.4 & \\
\hline & \multirow{4}{*}{ utilitarian } & empirical f. & 24 & 36 & 60 \\
\hline & & theoretical f. & 13.8 & 46.2 & 60 \\
\hline & & $\%$ responsibility & $40.0 \%$ & $60.0 \%$ & $100.0 \%$ \\
\hline & & $\begin{array}{l}\text { adjusted standardised } \\
\text { residuals }\end{array}$ & 3.2 & -3.2 & \\
\hline & \multirow{4}{*}{ biocentric } & empirical f. & 38 & 85 & 123 \\
\hline & & theoretical f. & 28.3 & 94.7 & 123 \\
\hline & & $\%$ responsibility & $30.9 \%$ & $69.1 \%$ & $100.0 \%$ \\
\hline & & $\begin{array}{l}\text { adjusted standardised } \\
\text { residuals }\end{array}$ & 2.2 & -2.2 & \\
\hline & \multirow{4}{*}{ holistic } & empirical f. & 214 & 862 & 1076 \\
\hline & & theoretical f. & 247.9 & 828.1 & 1076 \\
\hline & & $\%$ responsibility & $19.9 \%$ & $80.1 \%$ & $100.0 \%$ \\
\hline & & $\begin{array}{l}\text { adjusted standardised } \\
\text { residuals }\end{array}$ & -5.9 & 5.9 & \\
\hline & \multirow{2}{*}{ Total } & $\mathrm{f}$ & 299 & 999 & 1298 \\
\hline & & $\%$ responsibility & $23.0 \%$ & $77.0 \%$ & $100.0 \%$ \\
\hline
\end{tabular}

3 To compare the results to the representative national sample, see Cifrić (2004). 


\subsection{Socio-ecological orientations}

In this part of the paper, the descriptive results on the instrument of socio-ecological orientations will be presented (for comparison, see Cifrić, 1990a, 1998a, 2004³, 2007; Rončević and Rafajac, 2012), followed by an overview of the results related to the differences between the socio-ecological orientations and the following independent variables: ethos, selection of the development paradigm, sex, year of study, mother's level of education, father's level of education, and field of study.

The statement that received most support from the students is that technological development provides new benefits for humankind (73.4\%) (Table 9). This was followed by the statements which operationalise naturalism; namely $70.1 \%$ of the students agree with the claim that "humans are just one of nature's beings and need to submit to the law of nature," $62.1 \%$ of the students think that "humans are just one of Earth's beings and are completely dependent on the law of nature," while $57.5 \%$ of the students agree that "nature preservation takes precedence over all other social responsibilities." A total of $57.2 \%$ of the students agree with the claim that social development should be subordinate to the law of nature, which is consistent with the results of the research conducted in 2010 (Rončević and Rafajac, 2012).

The participants expressed the greatest disagreement with and the least acceptance of the particles related to the anthropocentrism scale, where $83.3 \%$ of the students disagree with the claim that "humans are the absolute masters of nature in which they live and can behave towards it as they please," while only $10.7 \%$ of the participants agree with the stated claim. The lowest percentage of the participants (9.3\%) agree with the claim that "humans are the rulers of Earth and can have unlimited access to its resources," while $78.1 \%$ of the participants disagree. The participants also disagree with the remaining two claims which represent the anthropocentric point of view. Therefore, $63.7 \%$ of the participants disagree with the claim that it is a primordial human right to exploit nature's resources as they please (14.9\% agree with this claim), while $55 \%$ of the students disagree with the claim that "humans as the most developed beings on Earth should decide the fate of the entire plant and animal world" (26.5\% agree with the claim).

The students' attitudes towards technology point to a significant division in perception, where $27.3 \%$ of the students agree with the claim "Today, humans are in complete control of cutting-edge technology and therefore can prevent possible incidents," while $29.8 \%$ are undecided. It is interesting to note that in the research conducted in 2010, $56 \%$ of the participants disagreed with the stated claim, and today that percentage is lower $(42.8 \%)$. The results are similar when it comes to the remaining particles on the technocentric scale of socio-ecological orientations; for example, one third of the students agree with the claim that "only modern technology can ensure better prospects," one third disagree, and one third are not sure or are undecided. In other words, similar to the research conducted on the same population in 2010 (Rončević and Rafajac, 2012), it can be concluded that the students express a critical attitude towards modern technology. 
Table 9. Descriptive statistics on the instrument of socio-ecological orientations

\begin{tabular}{|c|c|c|c|c|c|c|c|c|}
\hline & & 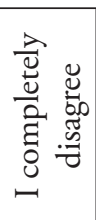 & 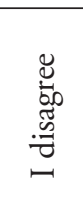 & 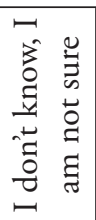 & 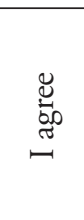 & 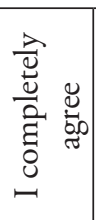 & M & SD \\
\hline & & \multicolumn{5}{|c|}{$\%$} & & \\
\hline 1. & $\begin{array}{l}\text { Humans are the absolute masters } \\
\text { of nature in which they live and } \\
\text { can behave toward it as they } \\
\text { please. }\end{array}$ & 47.4 & 35.9 & 6.0 & 6.3 & 4.4 & 1.84 & 1.077 \\
\hline 2. & $\begin{array}{l}\text { Technological development } \\
\text { provides new benefits for } \\
\text { humankind. }\end{array}$ & 1.3 & 7.9 & 17.4 & 54.8 & 18.6 & 3.82 & 0.873 \\
\hline 3. & $\begin{array}{l}\text { Humans are just one of nature's } \\
\text { beings and need to submit to the } \\
\text { law of nature. }\end{array}$ & 1.8 & 9.0 & 19.1 & 48.8 & 21.3 & 3.79 & 0.939 \\
\hline 4. & $\begin{array}{l}\text { It is a primordial human right to } \\
\text { exploit nature's resources as they } \\
\text { please. }\end{array}$ & 18.6 & 45.1 & 21.5 & 12.1 & 2.8 & 2.35 & 1.005 \\
\hline 5. & $\begin{array}{l}\text { Today, humans are in complete } \\
\text { control of cutting-edge technology } \\
\text { and therefore can prevent possible } \\
\text { incidents. }\end{array}$ & 8.2 & 34.6 & 29.8 & 23.0 & 4.3 & 2.80 & 1.020 \\
\hline 6. & $\begin{array}{l}\text { Social development should be } \\
\text { subordinate to the law of nature. }\end{array}$ & 2.1 & 10.3 & 30.4 & 44.6 & 12.6 & 3.55 & 0.912 \\
\hline 7. & $\begin{array}{l}\text { Humans as the most developed } \\
\text { beings on Earth should decide the } \\
\text { fate of the entire plant and animal } \\
\text { world. }\end{array}$ & 23.1 & 31.9 & 18.4 & 18.3 & 8.2 & 2.57 & 1.253 \\
\hline 8. & $\begin{array}{l}\text { Only modern technology can } \\
\text { ensure better prospects. }\end{array}$ & 7.9 & 29.6 & 34.6 & 21.0 & 7.0 & 2.90 & 1.043 \\
\hline 9. & $\begin{array}{l}\text { Nature preservation takes } \\
\text { precedence over all other social } \\
\text { responsibilities. }\end{array}$ & 1.5 & 13.4 & 27.7 & 42.7 & 14.8 & 3.56 & 0.950 \\
\hline 10. & $\begin{array}{l}\text { Humans are the rulers of Earth } \\
\text { and can have unlimited access to } \\
\text { its resources. }\end{array}$ & 37.0 & 41.1 & 12.6 & 7.0 & 2.3 & 1.96 & 0.991 \\
\hline 11. & $\begin{array}{l}\text { Modern technology has a lot } \\
\text { more positive than negative } \\
\text { characteristics. }\end{array}$ & 3.4 & 18.0 & 38.7 & 31.0 & 8.9 & 3.24 & 0.963 \\
\hline 12. & $\begin{array}{l}\text { Humans are just one of Earth's } \\
\text { beings and are completely } \\
\text { dependent on the law of nature. }\end{array}$ & 2.4 & 10.7 & 24.8 & 41.9 & 20.2 & 3.67 & 0.993 \\
\hline
\end{tabular}


A statistically significant difference between the socio-ecological orientations and ethos types was determined through the application of the one-way analysis of variance (Table 10). On the anthropocentrism scale, the holistic ethos type obtained a lower result in comparison to the remaining three groups. Similarly, the biocentric ethos type obtained a statistically significant lower result on the anthropocentrism scale. The holistic ethos type exhibited a higher result on the naturalism scale in comparison to other ethos types, and a lower result in comparison to other ethos types on the technocentrism scale. The effect size in all three cases is small.

Table 10. Differences between the socio-ecological orientations and ethos types: ANOVA

\begin{tabular}{|c|c|c|c|c|c|c|c|c|}
\hline $\begin{array}{l}\text { Socio-ecological } \\
\text { orientations }\end{array}$ & Ethos types & M & SD & $\mathrm{F}$ & df, df & $\mathrm{p}$ & difference & $\begin{array}{c}\text { Eta } \\
\text {-squared }\end{array}$ \\
\hline \multirow{5}{*}{ anthropocentrism } & 1. egocentric & 2.90 & 0.920 & \multirow[t]{5}{*}{25.761} & \multirow{5}{*}{$\begin{array}{r}3 \\
1304\end{array}$} & \multirow[t]{5}{*}{0.000} & \multirow{5}{*}{$\begin{array}{r}4<1,2,3 \\
3<1\end{array}$} & \multirow[t]{5}{*}{0.056} \\
\hline & 2. utilitarian & 2.63 & 0.735 & & & & & \\
\hline & 3. biocentric & 2.39 & 0.797 & & & & & \\
\hline & 4. holistic & 2.10 & 0.764 & & & & & \\
\hline & Total & 2.18 & 0.793 & & & & & \\
\hline \multirow{5}{*}{ naturalism } & 1. egocentric & 3.21 & 0.810 & \multirow[t]{5}{*}{20.958} & \multirow{5}{*}{$\begin{array}{r}3 \\
1281\end{array}$} & \multirow[t]{5}{*}{0.000} & \multirow[t]{5}{*}{$4>1,2,3$} & \multirow[t]{5}{*}{0.047} \\
\hline & 2. utilitarian & 3.21 & 0.636 & & & & & \\
\hline & 3. biocentric & 3.45 & 0.555 & & & & & \\
\hline & 4. holistic & 3.71 & 0.668 & & & & & \\
\hline & Total & 3.64 & 0.676 & & & & & \\
\hline \multirow{5}{*}{ technocentrism } & 1. egocentric & 3.46 & 0.854 & \multirow[t]{5}{*}{7.532} & \multirow{5}{*}{$\begin{array}{r}3 \\
1297\end{array}$} & \multirow[t]{5}{*}{0.000} & \multirow[t]{5}{*}{$4<1,2,3$} & \multirow[t]{5}{*}{0.017} \\
\hline & 2. utilitarian & 3.43 & 0.714 & & & & & \\
\hline & 3. biocentric & 3.31 & 0.612 & & & & & \\
\hline & 4. holistic & 3.15 & 0.661 & & & & & \\
\hline & Total & 3.19 & 0.670 & & & & & \\
\hline
\end{tabular}

In the analysis of differences with regard to the parents' level of education, the difference was not obtained on the variable of the mother's level of education. On the variable of the father's level of education, the difference was obtained only on the socio-ecological orientation of technocentrism $(\mathrm{F}[3,1299]=4.075, \mathrm{p}=0.007)$. The participants whose fathers completed secondary education demonstrate a lower result on the stated scale $(\mathrm{M}=3.06, \mathrm{SD}=0.707)$ in comparison to the participants whose fathers obtained a master's or doctoral degree $(\mathrm{M}=3.38, \mathrm{SD}=0.703)$. Eta-squared is a small value (0.009). The differences between the remaining groups were not determined.

The difference with regard to the year of study was obtained only on the anthropocentrism scale $(\mathrm{t}[1109.625]=3.993, \mathrm{p}=0.000)$. The participants in their initial years of study demonstrate a lower result $(\mathrm{M}=2.06, \mathrm{SD}=0.74)$ in comparison to the participants in their final years of study $(\mathrm{M}=2.25, \mathrm{SD}=0.817)$. Eta-squared is a small value (0.014). 
The difference with regard to the variable of sex was obtained on all three socio-ecological orientations. The female participants demonstrate a lower result on the anthropocentrism and technocentrisam scales (a medium effect size), and a higher result on the naturalism scale (a small effect size) in comparison to the male participants (Table 11). In other words, $10.3 \%$ of the variability of the socio-ecological orientation of anthropocentrism can be explained with the effect of sex, as well as $8.3 \%$ of the variability of the socio-ecological orientation of technocentrism.

Table 11. T-test difference between the socio-ecological orientations and sex

\begin{tabular}{|c|c|c|c|c|c|c|c|}
\hline & & M & SD & $\mathrm{t}$ & $\mathrm{df}$ & $\begin{array}{c}\text { Sig. } \\
(2-\text { tailed })\end{array}$ & $\begin{array}{c}\text { Eta- } \\
\text { squared }\end{array}$ \\
\hline \multirow{2}{*}{ anthropocentrism } & 1 female & 2.03 & 0.728 & \multirow{2}{*}{-9.523} & \multirow{2}{*}{787.108} & \multirow{2}{*}{0.000} & \multirow{2}{*}{0,103} \\
\hline & 2 male & 2.47 & 0.827 & & & & \\
\hline \multirow{2}{*}{ naturalism } & 1 female & 3.70 & 0.654 & \multirow{2}{*}{4.62} & \multirow{2}{*}{1292} & \multirow{2}{*}{0.000} & \multirow{2}{*}{0,016} \\
\hline & 2 male & 3.52 & 0.709 & & & & \\
\hline \multirow{2}{*}{ technocentrism } & 1 female & 3.08 & 0.623 & \multirow{2}{*}{-8.348} & \multirow{2}{*}{774.129} & \multirow{2}{*}{0.000} & \multirow{2}{*}{0,083} \\
\hline & 2 male & 3.41 & 0.706 & & & & \\
\hline
\end{tabular}

With regard to the field of study, the difference was obtained on the anthropocentrism and technocentrism scales, but not on the naturalism scale. The students from the field of humanities / social sciences and arts, and biomedicine and medicine demonstrate a lower result on the anthropocentrism ${ }^{4}$ and technocentrism ${ }^{5}$ scales in comparison to the students from the field of technical and biotechnical sciences. The effect size is small. The participants who selected the "new environmental paradigm" demonstrate a lower result on the anthropocentrism scale (medium effect size) and technocentrism scale (small effect size), and a higher result on the naturalism scale (small effect size) in comparison to the participants who selected "faster economic development accompanied by greater environmental pollution” (Table 12).

\subsection{Pro-environmental behaviour}

The instrument developed by R. Bertoldo (2014) was used to measure pro-environmental behaviour. The instrument consists of 15 particles on which the participants assess the frequency of the specific pro-environmental behaviour on a scale from 1 (never) to 5 (always).

$4 \mathrm{~F}(3,1315)=6,856, \mathrm{p}=0,000, \mathrm{M}_{\mathrm{DHU}}=2,10, \mathrm{SD}_{\mathrm{DHU}}=0,81 ; \mathrm{M}_{\mathrm{BMiZ}}=2,13, \mathrm{SD}_{\mathrm{BMiZ}}=0,793 ; \mathrm{M}_{\mathrm{TiBT}}=2,33$, $\mathrm{SD}_{\mathrm{TiBT}}=0,792 \cdot \mu^{2}=0,015$

$5 \mathrm{~F}(3,1308)=5,544, \mathrm{p}=0,001, \mathrm{M}_{\mathrm{DHU}}=3,14, \quad \mathrm{SD}_{\mathrm{DHU}}=0,655 ; \mathrm{M}_{\mathrm{BMiZ}}=3,14, \quad \mathrm{SD}_{\mathrm{BMiZ}}=0,667 ; \mathrm{M}_{\mathrm{TiBT}}=3,3$, $\mathrm{SD}_{\mathrm{TiBT}}=0,655 \cdot \mu^{2}=0,013$ 
Table 12. T-test difference between the socio-ecological orientations and preference of the development paradigm

\begin{tabular}{|c|c|c|c|c|c|c|c|}
\hline & & M & SD & $\mathrm{t}$ & df & 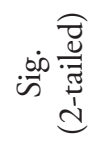 & 尝营 \\
\hline \multirow{2}{*}{ 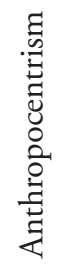 } & $\begin{array}{l}1 \text { faster economic development } \\
\text { accompanied by greater } \\
\text { environmental pollution }\end{array}$ & 2.46 & 0.859 & \multirow{2}{*}{6.771} & \multirow{2}{*}{429.898} & \multirow{2}{*}{0.000} & \multirow{2}{*}{0.096} \\
\hline & $\begin{array}{l}2 \text { slower economic development } \\
\text { accompanied by stronger } \\
\text { environmental protection }\end{array}$ & 2.08 & 0.747 & & & & \\
\hline \multirow{2}{*}{ 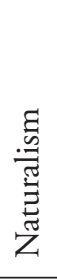 } & $\begin{array}{l}1 \text { faster economic development } \\
\text { accompanied by greater } \\
\text { environmental pollution }\end{array}$ & 3.35 & 0.686 & \multirow{2}{*}{-8.596} & \multirow{2}{*}{1251} & \multirow{2}{*}{0.000} & \multirow[t]{2}{*}{0.056} \\
\hline & $\begin{array}{l}2 \text { slower economic development } \\
\text { accompanied by stronger } \\
\text { environmental protection }\end{array}$ & 3.73 & 0.652 & & & & \\
\hline \multirow{2}{*}{ 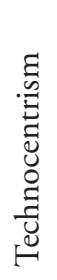 } & $\begin{array}{l}1 \text { faster economic development } \\
\text { accompanied by greater } \\
\text { environmental pollution }\end{array}$ & 3.45 & 0.672 & \multirow{2}{*}{7.774} & \multirow{2}{*}{1268} & \multirow{2}{*}{0.000} & \multirow{2}{*}{0.045} \\
\hline & $\begin{array}{l}2 \text { slower economic development } \\
\text { accompanied by stronger } \\
\text { environmental protection }\end{array}$ & 3.11 & 0.649 & & & & \\
\hline
\end{tabular}

The majority of the participants responded that they often or almost always turn off the lights when they leave the room $(91.2 \%)$, and that they turn off air or heating before opening the windows (81.7\%) (Table 13). Other claims related to saving resources also have a high percentage of agreement; for example, $64.5 \%$ of the participants are careful not to waste water at home, more than half of the students use energy saving lamps (53.1\%) and turn off devices rather than leave them on the charger $(51.2 \%)$.

In the context of energy efficiency, the participants express the largest disagreement with the claim "I forget to turn off the lights in the rooms where there is nobody" (75.7\%), followed by the claim "At home, I use electricity without worrying about electric energy consumption" $(51.9 \%)$. These results are not surprising if we take into account the fact that the University of Rijeka students are most often tenants.

When it comes to the remaining pro-environmental behaviours, $51.6 \%$ of the participants claim that they utilise reusable bags when shopping, and $43.6 \%$ of the students often or always sort and dispose of glass waste in the appropriate containers. Only $39.2 \%$ of the participants dispose of used batteries in specially marked containers, and $34.1 \%$ sort and dispose of paper waste in the appropriate containers. 
Table 13. Descriptive statistics on the instrument of pro-environmental behaviour

\begin{tabular}{|c|c|c|c|c|c|c|c|c|}
\hline & & 亗 & $\begin{array}{l}\frac{\lambda}{\pi} \\
\frac{\pi}{\pi}\end{array}$ & 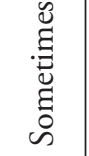 & 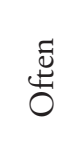 & $\frac{\sqrt[5]{3}}{4}$ & M & SD \\
\hline & & \multicolumn{5}{|c|}{$\%$} & & \\
\hline 2 & $\begin{array}{l}\text { I turn off the lights when leaving the } \\
\text { room. }\end{array}$ & 0.7 & 2.5 & 5.7 & 24.4 & 66.8 & 4.54 & 0.774 \\
\hline 4 & $\begin{array}{l}\text { I turn off air or heating before } \\
\text { opening the window. }\end{array}$ & 1.9 & 4.6 & 11.9 & 22.5 & 59.2 & 4.33 & 0.978 \\
\hline 5 & $\begin{array}{l}\text { At home, I am careful with water } \\
\text { consumption. }\end{array}$ & 3.3 & 8.6 & 23.6 & 32.4 & 32.1 & 3.82 & 1.078 \\
\hline 3 & I use energy saving lamps. & 6.9 & 10.5 & 29.5 & 30.6 & 22.5 & 3.51 & 1.151 \\
\hline 11 & $\begin{array}{l}\text { I bring reusable bags with me when } \\
\text { I go grocery shopping. }\end{array}$ & 9.7 & 13.8 & 24.9 & 27.7 & 23.9 & 3.42 & 1.258 \\
\hline 14 & $\begin{array}{l}\text { I am careful not to waste water at } \\
\text { home. }\end{array}$ & 5.8 & 13.4 & 31.6 & 31.7 & 17.5 & 3.42 & 1.099 \\
\hline 1 & $\begin{array}{l}\text { I turn off devices (computer, mobile } \\
\text { phone) rather than to leave them on } \\
\text { the charger. }\end{array}$ & 10.7 & 17.1 & 21.1 & 27.2 & 24 & 3.37 & 1.302 \\
\hline 9 & $\begin{array}{l}\text { I turn electrical appliances off so } \\
\text { that they would not be in standby. }\end{array}$ & 10.3 & 18.7 & 27.1 & 24.5 & 19.5 & 3.24 & 1.25 \\
\hline 15 & $\begin{array}{l}\text { I sort and dispose of my glass waste } \\
\text { in the appropriate containers. }\end{array}$ & 12.2 & 17.7 & 26.5 & 22.7 & 20.9 & 3.22 & 1.296 \\
\hline 7 & $\begin{array}{l}\text { I dispose of used batteries in } \\
\text { specially marked containers. }\end{array}$ & 18.8 & 19.8 & 22.3 & 17.2 & 22 & 3.04 & 1.415 \\
\hline 12 & $\begin{array}{l}\text { I forget to sort and dispose of the } \\
\text { paper waste in the appropriate } \\
\text { container. I dispose of it together } \\
\text { with the regular garbage. }\end{array}$ & 15.7 & 19.1 & 30.9 & 21.3 & 13 & 2.97 & 1.246 \\
\hline 6 & $\begin{array}{l}\text { I find it boring to sort the recyclable } \\
\text { garbage and dispose of it in the } \\
\text { appropriate container. }\end{array}$ & 14.7 & 19.4 & 34.6 & 17.8 & 13.4 & 2.96 & 1.223 \\
\hline 13 & I buy organically grown fruit. & 10.7 & 25.7 & 40.2 & 17.7 & 5.7 & 2.82 & 1.029 \\
\hline 10 & $\begin{array}{l}\text { At home, I use electricity without } \\
\text { worrying about electric energy } \\
\text { consumption. }\end{array}$ & 23 & 28.9 & 24.6 & 16.2 & 7.3 & 2.56 & 1.213 \\
\hline 8 & $\begin{array}{l}\text { I forget to turn off the lights in the } \\
\text { rooms where there is nobody. }\end{array}$ & 43.6 & 32.1 & 16 & 5.8 & 2.4 & 1.91 & 1.019 \\
\hline
\end{tabular}


The pro-environmental behaviour that the participants engage in the least is buying organically grown fruit. Only $23.4 \%$ of the participants often or always buy organically grown fruit, $40.2 \%$ sometimes, and $36.4 \%$ rarely or never. Since the studied population are students, these results are not unexpected. It can be concluded that the majority of students engage in pro-environmental behaviours which contribute to financial savings, while a smaller percentage of the students express a distinct ecological awareness and environmental care.

In order to create a pro-environmental behaviour scale, particles 6, 8, 10 and 12 were recoded. Furthermore, Cornbach's alpha coefficient was calculated (0.776). On the basis of the criterion that the item-total correlation should be over 0.3 , two particles were disregarded: particle 8 "I forget to turn off the lights in the rooms where there is nobody," and particle 13 "I buy organically grown fruit." The final alpha value was 0.771 . Therefore, the final pro-environmental behaviour scale consisted of 13 particles.

The differences on the pro-environmental behaviour scale and the following independent variables were tested: selection of development paradigm, sex, year of study, mother's level of education, father's level of education, and field of study.

The difference with regard to sex, year of study and preference of the development paradigm was determined through the application of T-tests. The female participants ${ }^{6}$, students in their final years of study ${ }^{7}$, and the participants who chose the "new environmental paradigm" demonstrate a statistically significant higher result on the pro-environmental scale in comparison to the male participants, students in their initial years of study and participants who chose the "faster economic development accompanied by greater environmental pollution." The differences with regard to the field of study and the parents' level of education were not obtained.

\subsection{Connection between the socio-ecological orientations and pro-environmental behaviour}

A multiple regression analysis was conducted in order to determine if the pro-environmental behaviours could be predicted based on the socio-ecological orientations (Table 14). The pro-environmental behaviour scale acted as the criterion variable, and the anthropocentrism, naturalism and technocentrism scales acted as the predictor variables. The result of the regression analysis demonstrates that there is a statistically significant relationship between the pro-environmental behaviour scale and the socio-ecological orientations $(R=0.262 ; F[3,1204]=29.698 ; p=0.000, p<0.05)$. The socio-ecological orientations explain $6.9 \%$ of the pro-environmental behaviour variance. The anthropocentrism and naturalism predictors make a statistically significant contribution to the explanation of the criterion variance, while the technocentrism predictor does not make a statistically significant contribution. The anthropocentrism is negatively correlated, which means that the higher result on the anthropocentrism scale is connected to the lower results on

$6(\mathrm{t}(1290)=5,639, \mathrm{p}=0,000)\left(\mathrm{M}_{1}=3,08, \mathrm{SD}=0,521\right),\left(\mathrm{M}_{2}=2,9, \mathrm{SD}=0,529\right) ; \mu^{2}=0,024$

$7(\mathrm{t}(1292)=-3,177, \mathrm{p}=0,000)\left(\mathrm{M}_{1}=2,99, \mathrm{SD}=0,538\right),\left(\mathrm{M}_{2}=3,09, \mathrm{SD}=0,514 ; \mu^{2}=0,008\right.$

$8(\mathrm{t}(1253)=-8,066, \mathrm{p}=0,000)\left(\mathrm{M}_{1}=2,81, \mathrm{SD}=0,551\right),\left(\mathrm{M}_{2}=3,1, \mathrm{SD}=0,509\right) ; \mu^{2}=0,049$ 
the pro-environmental behaviour scale. The socio-ecological orientation of naturalism is positively correlated, which means that the higher result on the naturalism scale is connected to the higher results on the pro-environmental behaviour scale.

Table 14. Multiple regression of the socio-ecological orientations (predictors) and the proenvironmental behaviour scale (criterion)

\begin{tabular}{|c|c|c|c|c|c|}
\hline \multirow{2}{*}{$\mathrm{R}^{2}=0.069$} & \multirow{2}{*}{$\begin{array}{c}\text { Standardised } \\
\text { beta coefficients }\end{array}$} & \multirow{2}{*}{ t-ratio } & \multirow{2}{*}{$\mathrm{p}$} & \multicolumn{2}{|c|}{ Correlation } \\
\hline & & & & Direct & Partial \\
\hline (Constant) & & 23,807 & .000 & & \\
\hline anthropocentrism & $-0,142$ & -4.48 & .000 & -0.211 & -0.128 \\
\hline naturalism & 0,160 & 5.435 & .000 & 0.211 & 0.155 \\
\hline technocentrism & $-0,042$ & -1.4 & 0.162 & -0.119 & -0.04 \\
\hline
\end{tabular}

\section{CONCLUSION}

The research results support the socio-ecological perspective, and therefore it can be used for the operationalisation of further research. In order to summarise the research results, it can be concluded that students predominantly represent the holistic ethos type of responsibility $(82.2 \%)$, which confirms one of the hypotheses. Also, as was expected based on previous research, a contingency association with regard to sex and year of study was determined. The male participants are more represented in the category of the egocentric ethos type of responsibility, while the female participants are more represented in the group of the holistic ethos type. The students who are at the beginning of their higher education are more represented in the categories of the egocentric, utilitarian and biocentric ethos types, while the students in their final years of study are more represented in the group of the holistic ethos type of responsibility. On the variable that was used to measure the moral dilemma whose selection has different consequences for the environment as an outcome, most participants chose the new environmental paradigm, which is in accordance with the prior studies and the formulated hypothesis. Nevertheless, the contingency association was determined according to sex and year of study. The male participants and students who are at the beginning of their studies are more represented in the selection category of "faster economic development accompanied by greater environmental pollution," while the female participants and students in their final years of study are more represented in the selection group of the new environmental paradigm. Furthermore, the egocentric, utilitarian and biocentric ethos types of responsibility are more represented than was expected in the selection of the response "faster economic development accompanied by greater environmental pollution," while the holistic ethos type of responsibility is more represented in the selection of the ecological development paradigm. The parents' level of education and the field of study did not manifest as significant. 
In the context of socio-ecological orientations, the claim that received most support from the participants is related to the particle of technocentrism: "Technological development provides new benefits for humankind" (73.4\%), but on all the other particles of technocentrism their attitudes are divided. The remaining claims which elicit a high degree of agreement from the participants relate to the particles that were used to measure naturalism. For example, $70.1 \%$ of the students agree with the claim that "humans are just one of nature's beings and need to submit to the law of nature," $62.1 \%$ think that "humans are just one of Earth's beings and are completely dependent on the law of nature", which partly confirms the hypothesis. On the other hand, $83.3 \%$ of the participants reject the attitude that "humans are the absolute masters of nature in which they live and can behave toward it as they please." The results indicate the presence of a certain level of ecological awareness. On the created scales of socio-ecological orientations, statistically significant differences were obtained with regard to almost all the independent variables: ethos types of responsibility, sex, year of study, field of study, selection of development paradigm and father's level of education, while the mother's level of education did not demonstrate statistical significance.

Pro-environmental behaviour on the instrument predominantly relates to the everyday activities which are common for the student population. Nevertheless, apart from the pro-environmental behaviour such as "I turn off the lights when I leave the room" (91.2\%) and "I turn off air or heating before opening the window" (81.7\%), all the other pro-environmental behaviours are less represented. For example, $51.6 \%$ of the participants state that they utilise reusable bags when they go shopping, $43.6 \%$ of the students state that they often or always sort and dispose of glass waste in the appropriate containers, while only $39.2 \%$ dispose of batteries in specially marked containers, and $34.1 \%$ dispose of paper waste in the appropriate containers. The stated results lead to two conclusions. Even though the students express a relatively high percentage of sensibility towards environmental issues in the context of the socio-ecological identities, according to self-evaluation most of them express environmental behaviours which primarily contribute to financial savings, while a considerably smaller percentage of students express environmental behaviours which do not have a visible influence (e.g., recycling of paper, glass and batteries). This result supports the acceptance of the fourth hypothesis. Similar results were obtained in the research conducted in 2006 on the sample of students in the Koprivnica-Križevci County with the goal of examining the students' attitudes and behaviours (Kantar et al., 2009). The authors concluded that most participants display an awareness of the fact that humankind predominantly contributes to the Earth's pollution, but do not feel personally responsible for the fact, and do not display interest in active environmental protection. When it comes to the students' behaviour, they actively participate in the disposal of some types of waste; however, the results show that they do not appropriately dispose of the waste when it does not provide immediate benefits. It was determined that the female participants, students in their final years of study and participants who chose the "new environmental paradigm" demonstrate a statistically significant higher result on the pro-environmental behaviour scale in comparison to the 
male participants, students at the beginning of their study and participants who chose "faster economic development accompanied by greater environmental pollution." The differences with regard to the field of study and the parents' level of education were not obtained. To conclude, it was determined that the anthropocentrism predictor was negatively correlated to pro-environmental behaviour, and naturalism was positively correlated to pro-environmental behaviour, while the technocentrism predictor did not contribute to the explanation of the criterion variance.

It should not be forgotten that these young people are individuals who will one day educate future generations and make new development decisions. In 1991, Orr stated that it is the highly educated population (of the world) that makes unsustainable decisions whose consequences result in a notably negative influence on the environment. The results of this research and prior studies support the conclusion that the duration of studying and sex are connected to the increase in the sense of responsibility towards the environment, which is an important finding that should influence educational policy. To be more precise, since the results point to a conclusion that men are less environmentally sensitive, as well as more represented within the structure of the governing elite in comparison to women, there is a need to focus the educational content regarding environmental issues on this population.

The educational content influences the individual and their identity, which highlights the importance of the integrated exploration and teaching of environmental issues through all the courses and study programmes. Hence, all the teachers have a great responsibility, and in particular, an academic profession whose duty is to accept environmental issues as part of the teaching programme, within the framework of its possibilities. This is supported by the fact that $57.9 \%$ of the University of Rijeka students are interested or exceptionally interested in the inclusion of the content "Climate change and its influence on the future of society" into their study programme. If they are not educated on environmental issues, and the wider issue of sustainable development, the question is if sustainable development has any chances (Rončević and Rafajac, 2012). But the circle of individuals, associations, and political organizations that advocate the change of modern society's development paradigm is becoming increasingly wider. The new paradigm would acknowledge the strong scientific evidence concerning the realistic threats to the survival of life on Earth, and would be based on the rational use of natural resources, the use of renewable energy sources, waste separation and recycling, attention to organic diet, etc. The prerequisite for the paradigm's realisation is the active pro-ecological behaviour of people on personal and group levels in all aspects of the practice. 


\section{REFERENCES}

Bertoldo, R. (2014). Valorização social do pró-ambientalismo enquadrado por normas formais: uma análise psicossocial comparativa entre Brasil e Portugal (Unpublished doctoral dissertation). Lisbon University Institute, ISCTE-IUL. URL: https://repositorio.iscte-iul.pt/handle/10071/8490 (November 27, 2015).

Cifrić, I. (1990a). Socijalno-ekološke orijentacije u selu i gradu. Sociologija i prostor, 109-110: 201-216.

Cifrić I. (1990b). Latentne dimenzije socijaloekoloških koncepcija. Sociologija, 32(1-2): 129:141.

Cifrić, I. (1992). Čovjek između prirode i tehnike. Revija za sociologiju, 23(3-4): 179-192.

Cifrić, I. (1994a). Antropocentrizam i naturalizam: uporišta modernog mišljenja, Socijalna ekologija, 3(2): 123-147.

Cifrić, I. (1994b). Napredak i opstanak. Zagreb: Hrvatsko sociološko društvo i Zavod za sociologiju Filozofskog fakulteta

Cifrić, I. (1997a). Traganje za svjetskim ekološkim etosom. Socijalna ekologija, 6(1-2): 53-70.

Cifrić, I. (1997b). Etos odgovornosti i ekološka osjetljivost, Socijalna ekologija, 6 (3): 253- 272.

Cifrić, I. (1998). Zaštita okoliša u obnovi i razvoju Hrvatske. Društvena istraživanja, 7(6 (38)): 793-814.

Cifrić, I. (2004). Orijentacijski identitet. Socijalnoekološke orijentacije kao obilježja identiteta. Socijalna ekologija, 13(3-4): 221-256.

Cifrić, I. (2005). Ekološka edukacija. Filozofska istraživanja, 25(2): 327-344.

Cifrić, I. (2007). Pravo životinjskih vrsta na život. Sociologija i prostor, 45(1(175)): 3-27.

Cohen, J. (1988). Statistical power analysis for the behavioral sciences. Hillsdale, NJ: Erlbaum.

Crumpei, I., Boncu S., Crumpei, G. (2014). Environmental Attitudes and Ecological Moral Reasoning in Romanian Students. Procedia - Social and Behavioral Sciences, 114: $461-465$.

D’Alisa, G., Demaria, F., Kallis, G. (2016). Odrast: Pojmovnik za novu eru. Zaprešić: Fraktura, IPE.

de Leeuw, A., Valois, P., Ajzen, I., Schmidt P. (2014). Using the theory of planned behavior to identify key beliefs underlying proenvironmental behavior in high-school students: Implications for educational interventions. Journal of Environmental Psychology, 42: 128-138.

Domac, J., Kufrin, K., Šegon, V. (2004). Obnovljivi izvori energije i energetska efikasnost. Stavovi i mišljenja stanovnika Zagreba i Rijeke. Socijalna ekologija, 13(3-4): 347-364.

Duman-Yuksel, U. and Ozkazanc, S. (2015). Investigation of the Environmental Attitudes and Approaches of University Students'. Procedia - Social and Behavioral Sciences, 197: 2191-2200. 
Field, A. (2013). Discovering statistics Using IBM SPSS Statistics. Thousand Oaks, CA: Sage Publications.

Gatersleben, B., Murtagh, N., Abrahamse, W. (2014). Values, identity and pro-environmental behaviour. Contemporary Social Science, 9(4): 374-392.

Kantar, S., Razum, O., Svržnjak, K. (2009). Zaštita okoliša u stavovima i ponašanju studenata Koprivničko - križevačke županije. Socijalna ekologija, 18(2): 169-188.

Kufrin, K., Domac, J., Šegon, V. (2004). Informiranost o obnovljivim izvorima energije i energetskoj efikasnosti. Socijalna ekologija, 13(3-4): 325-346.

Miles, J. and Shevlin, M. (2001). Applying Regression and Correlation: A Guide for Students and Researchers. London: Sage.

Müderrisoğlu, H. and Altanlaru, A. (2011). Attitudes and behaviors of undergraduate students toward environmental issues. International Journal of Environmental Science and Technology, 8 (1): 159-168.

Orr, D. (1991). What Is Education For? Six myths about the foundations of modern education, and six new principles to replace them. In Context, 27. URL: http:// www.context.org/iclib/ic27/ (May 18, 2016).

Prabawa-Sear, K. and Baudains, C. (2011). Asking the Participants: Students' Views on Their Environmental Attitudes, Behaviours, Motivators and Barriers. Australian Journal of Environmental Education, 27(2): 219-228.

Rončević, N. and Rafajac, B. (2012). Održivi razvoj izazov za sveučilište?. Rijeka: Filozofski fakultet u Rijeci.

Unanue, W., Vignoles, V. L., Dittmar, H., Vansteenkiste M. (2016). Life goals predict environmental behavior: Cross-cultural and longitudinal evidence. Journal of Environmental Psychology, 46: 10-22.

Vicente, M., Fernandez, S., Izagirre, O. (2012). Environmental knowledge and other variables affecting pro-environmental behaviour: comparison of university students from emerging and advanced countries. Journal of Cleaner Production, 61: 130-138. 


\title{
STAVOVI I PONAŠANJA STUDENATA PREMA EKOLOŠKOJ PROBLEMATICI
}

\section{Sažetak}

\section{Nena Rončević i Klara Cvetković}

Cilj je istraživanja bio opisati i analizirati stavove i ponašanja studentske populacije Sveučilišta u Rijeci $(N=1347)$ prema ekološkoj problematici. Podaci su prikupljeni tijekom ljetnog semestra u ak. god. 2015./2016. Radom se težilio istražiti povezanost sljedećih izmjerenih koncepata: socijalno-ekoloških orijentacija, proekološkog ponašanja, etos tipova i preferencije razvojne paradigme, te utvrditi razlike s obzirom na nezavisne varijable. Rezultati istraživanja ukazuju na zaključak kako studenti dominanto zastupaju holistički etos tip odgovornosti (82,2\%), te da većina ipak odabire novu ekološku paradigmu, tj. tvrdnju „sporiji ekonomski razvoj uz manje zagadenje okoliša", što je u skladu s rezultatima drugih istraživanja. Takoder, utvrdena je kontingencijska povezanost prema spolu i godini studija. Muškarci su zastupljeniji u kategoriji egocentričnog etos tipa odgovornosti i odabiru tvrdnje „brži ekonomski razvoj uz veće zagadenje okoliša", dok su žene zastupljenije u skupini holističkog etos tipa i odabiru nove ekološke paradigme. Studenti na početku visokoškolskog obrazovanja zastupljeniji su u kategorijama egocentričnog, utilitarističkog i biocentričkog etos tipa, dok su studenti završnih godina zastupljeniji u skupini holističkog etos tipa odgovornosti i odabiru nove ekološke paradigme. Na oblikovanim ljestvicama socijalnoekoloških orijentacija dobivene su statistički značajne razlike sobzirom na gotovo sve nezavisne varijable: etos tipove odgovornosti, spol, godinu studija, znanstveno područje studiranja, odabir razvojne paradigme i stupanj obrazovanja oca, dok se stupanj obrazovanja majke nije pokazao statistički značajan. Na ljestvici proekološkog ponašanja utvrđeno je da žene, studenti završnih godina studija $i$ ispitanici koji su odabrali „novu ekološku paradigmu" postižu statistički značajno veći rezultat u odnosu na muškarce, studente na početku školovanja $i$ ispitanike koji su odabrali tvrdnju „brži ekonomski razvoj uz veće zagadivanje okoliša“. Drugim riječima, može se tvrditi da su duljina školovanja i spol povezani s porastom osjećaja odgovornosti prema okolišu, što je važan nalaz koji mora imati utjecaja na obrazovnu politiku.

Ključne riječi: socijalnoekološke orijentacije, etos tipovi, razvojne paradigme, proekološko ponašanje, ekološko obrazovanje

\section{STELLUNGNAHMEN VON STUDENTEN ZUR ÖKO-PROBLEMATIK UND DEREN VERHALTEN DAZU}

\author{
Nena Rončević und Klara Cvetković
}

\section{Zusammenfassung}

Das Ziel der Forschung war es, die Stellungnahmen der studentischen Population der Universität in Rijeka $(N=1347)$ zur Öko-Problematik und deren Verhalten zu beschreiben und zu anaysieren. Die Daten wurden im Laufe des Sommersemesters im akadenischen Jahr 2015/2016 gesammelt. In der Arbeit wurde Versucht, die Verbindung folgender gemessenen Konzepte zu untersuchen: sozial-ökologische Orientierung, prö̈kologisches Verhalten, Ethos-Typen und Preferenzen des Entwicklungsparadigmas, außerdem galt es, Unterschiede im Hinblick auf unabhängige Variablen festzustellen. Die Forschungsergebnisse weisen auf den Schluss hin, dass die meisten Befragten zum holistischen Ethos-Typ der Verantwortung stehen (82,2\%), sowie dass die Mehrheit von ihnen das neue ökologische Paradigma wählt, d.h. die Behauptung „eine langsamere wirtschaftliche Entwicklung mit weniger Umweltverschmutzung", was im Einklang mit anderen Forschungsergebnissen steht. Auch wurde eine anteilsmäßige Verbindung nach Geschlecht und Studienjahr festgestellt. Männer sind eher in der Kathegorie des egozentrischen Ethos-Typen der Verantwortung und wählen die Behauptung: „eine schnellere wirtschaftliche Entwicklung mit mehr Umweltverschmutzung", während Frauen eher in der Gruppe des holistischen Ethos-Typen vertreten sind und neue ökologische 
Paradigmen wählen. Studenten, die sich am Anfang ibrer Hochschulbildung befinden, sind eher in Kategorien des egozentrischen, utilitären und biozentrischen Ethos-Typen vertreten, während Studenten der Abschlussjahre eher in der Gruppe des holistischen Ethos-Typen vertreten sind und neue ökologische Paradigmen wählen. Auf gebildeten Skalen der sozial-ökologischen Orientierung wurden statistisch relevante Unterschiede erhalten mit Bezug auf fast alle unabhängigen Variablen: Ethos-Typen der Verantwortung, Geschlecht, Studienjahr, wissenschaftliches Studiengebiet, Wahl der Entwicklungsparadigmas und Bildungsstufe des Vaters, während die Bildungsstufe der Mutter sich als nicht statistisch relevant erwiesen hat. Auf der Skala des proökologischen Verhaltens wurde festgestellt, dass Frauen, Studenten der Abschlussjahre und die Befragten, die das "neue ökologische Paradigma" gewählt haben, ein statistisch gesehen erheblich höheres Ergebnis erzielen als Männer, Studienanfänger und Befragte, die die Behauptung „eine schnellere wirtschaftliche Entwicklung mit mehr Umweltverschmutzung" wählten. Mit anderen Worten kann man behaupten, dass die Bildungsdauer und das Geschlecht mit Steigerung des Gefühls der Verantwortung der Umwelt gegenüber verbunden sind, was ein wichtiger Befund ist, der Einfluss auf die Bildungspolitik haben muss.

Schlüsselwörter: sozial-ökologische Orientierungen, Ethos-Typen, Entwicklungsparadigmen, proökologischen Verhaltens, ökologische Bildung 